\title{
Drinking Water Disinfection By-products and Their Carcinogenicity, A Review of Unseen Crisis
}

\author{
Hassan Aslani ${ }^{1,2}$, Mohammad-Salar Hosseini ${ }^{3}$, Sahar Mohammadi ${ }^{4,5}$ and Mohammad \\ Naghavi-Behzad (ii) $3,6,7,{ }^{*}$ \\ ${ }^{1}$ Health and Environment Research Center, Tabriz University of Medical Sciences, Tabriz, Iran \\ ${ }^{2}$ Department of Environmental Health Engineering, Faculty of Health, Tabriz University of Medical Sciences, Tabriz, Iran \\ ${ }^{3}$ Student Research Committee, Tabriz University of Medical Sciences, Tabriz, Iran \\ ${ }^{4}$ Department of Emergency Medicine, Zanjan University of Medical Sciences, Zanjan, Iran \\ ${ }^{5}$ Medical Philosophy and History Research Center, Tabriz University of Medical Sciences, Tabriz, Iran \\ ${ }^{6}$ Department of Clinical Research, University of Southern Denmark (SDU), Odense, Denmark \\ ${ }^{7}$ Social Determinants of Health Research Center, Tabriz University of Medical sciences, Tabriz, Iran \\ "Corresponding author: Student Research Committee, Tabriz University of Medical Science, Daneshgah Street, Tabriz, Eastern Azerbaijan, Iran. Tel: +45-91609622, Email: \\ mnb91@rsyd.dk; dr.naghavii@gmail.com
}

Received 2019 January 08; Revised 2019 April 13; Accepted 2019 May 11.

\begin{abstract}
Context: Cancer continues to be the first cause of mortality and morbidity all over the world, while the incidence of cancer is expected to increase by $50 \%$ over the next 20 years. Since the incidence of most of the cancers is increasing daily, it has been more important to find related environmental risk factors. The epidemiological evidence indicates the effect of disinfection byproducts (DBPs) through drinking water, as an environmental exposure, on most of the cancers. The goal of the current study was to combine the results of most recent publications regarding the relationship between DBPs and their carcinogenic effects.

Evidence Acquisition: Using the main keywords of "cancer", "drinking water", and "disinfection byproducts", a comprehensive search was done among several research databases.

Results: Based on the previous studies, DBPs could cause most types of cancers, mainly including gastrointestinal, renal, bladder, breast, liver, and thyroid cancers. Liver and renal cancers are the most common target organs for toxicity by DBPs. Among the various DBPs, trihalomethanes are the most studied due to their relatively high prevalence and concentration in drinking water. Also, haloacetic acids, such as trichloroacetic acid and dichloroacetic acid, have been known as one of the most affecting risk factors. Unregulated DBPs, such as Mutagen X and Formaldehyde, are also of importance as they mostly have irreversible systemic effects. Providing safe drinking water resources, restriction of unreasonable usage of disinfectants, and alternating disinfectants with less harmful products could be the possible ways to overcome this crisis.

Conclusions: Disinfection byproducts can result in cancer development, especially in liver and kidneys. Providing safe drinking water resources, using the membrane filters and changing the chlorination point are effective ways to encounter the risk of DBP poisoning.
\end{abstract}

Keywords: Drinking Water, Disinfection By-products, Carcinogenicity Tests, Mutagenicity Tests

\section{Context}

Cancer is a chief public health issue all around the world, which is considered as a lethal disease in most regions like the third leading cause of death in Iran and the second in United States $(1,2)$. Studying the cellular basis of cancer, most of the time an error in replication leads to a cancerous cell (3). On the molecular basis, cancer is a result of chromosome instability, DNA-repair defects, or aberrant DNA methylation $(4,5)$. Current evidence supports the idea that chemical exposures are associated with DNA-methylation and DNA-repair mechanisms, and, as a result, they could get the expression processes under influence and affect human health (6-9). Therefore, by studying the pathology of cancer, a considerable association between the exposure to particular chemicals and the onset of malignancy can be witnessed (5).

Disinfectants are the common chemicals used to remove pathogenic microbes and infectious particles in daily-used substances, like water, or in sanitary healthcare units, such as hospitals, health centers, public environments, and even indoors $(10,11)$. The amount of a disinfectant used to cleanse a surface or an area depends on the type of disinfectant and the desired level of disinfec- 
tion; for example, imagine a healthcare-related zone, filled up with bacteria spores; an adequate amount of aldehydes can eliminate almost all spores, but lots of phenolic disinfectants, as they just affect the tridimensional structure of proteins, cannot remove any of them (12).

In the water treatment industry, disinfection byproducts (DBPs), like chloroform, bromate, bromodichloromethane, trichloroacetic acid, and formaldehyde, are usually formed through the reaction of chlorine, most frequently used disinfectant, with some poisons, carbon-based substances, iodide, and other similar species, which are totally named natural organic matter (NOM) (13-15). As the nanomaterials' trace in pollution has been more scrutable, the role of carbon-based substances in the production of DBPs gets more obvious and could be considered as a remarkable issue in the modern nature (16).

Disinfection byproducts are commonly divided into two categories: hydrophobic and hydrophilic. The hydrophilic DBPs contain two major groups of chlorinated and non-chlorinated DBPs. The most common DBPs in drinking water are chlorinated DBPs. They are also divided into two classes: regulated and unregulated DBPs. Regulated DBPs are trihalomethanes (THMs), haloacetic acids (HAAs), and bromates. The major unregulated group of DBPs, on the other hand, includes chlorate and chlorite (13, 17-19). The most famous THMs are trichloromethane (commonly known as chloroform), bromodichloromethane, chlorodibromomethane, and tribromomethane (commonly known as bromoform). Haloacetic acids are a wider group with 3 subgroups, including monohaloacetic acids (monochloroacetic acid and monobromoacetic acid), dihaloacetic acids (dichloroacetic acid, dibromoacetic acid, and bromochloroacetic acid), and trihaloacetic acids (trichloroacetic acid, chlorodibromoaceti acid, bromodichloroacetic acid, and tribromoacetic acid). Trihalomethanes and HAAs are formed due to the reaction between chlorine and NOM in chlorinated water. Bromate and chlorite are also known as inorganic DBPs, which can be formed after water and wastewater disinfection by chlorine dioxide and ozone, particularly in water resources with high bromide content (20-22). Other halogenated DBPs are haloacetonitriles, cyanogen chloride, and mutagen X (MX). Also, the reaction of ozone with natural organic matter can lead to the formation of aldehydes, ketoacids, and carboxylic acids (5, 13, 17, 23-25).

Chemicals used as water and wastewater disinfectants are able to either destruct or completely inactivate microorganisms; so, they have an anti-life nature (26). As a result of this quiddity, they possibily can affect the healthy body cells. They make their influence on the fundamental mechanisms of the cells, and according to the pathology of cancer, a possible correlation between DBPs and cancer is not out of mind (27-29). The association between DBPs and various types of cancer has been previously demonstrated $(5,12,30,31)$. Also, the matter of DBPs in causing cancer has been studied previously (32-35). The role of the current review is to address the underlying mechanisms and discuss the most common cancers caused by the continuous exposure to DBPs. Furthermore, the effective treatment methods and mechanisms of DBPs removal in drinking water is provided.

\section{Evidence Acquisition}

During current narrative review, which was conducted between November 2017 and January 2019, the consequences of DBPs, which are led to cancer, were investigated. A comprehensive literature review of research databases, containing Medline, PubMed, Scopus, Embase, Google Scholar, Cochrane Library, Toxline, Pollution Abstracts, Water Resources Abstracts, and BIOSIS previews was performed, using the main keywords of "cancer", "drinking water", and "disinfection byproducts". Up to the end of the time period of the study, the published manuscripts were considered. Also, for improving the precision, a manual searching among the references of gathered articles was performed. MeSH terms and free text words were also included, regarding the inquiry method of some databases. Of total 7420 gathered articles, 4300 articles were excluded due to inconformity with the subject. From the remaining 3120 articles, 2510 were excluded after checking the abstracts by the research team. After inspecting the full text of the remaining 610 articles, 103 eligible articles were selected. The qualified manuscripts were reviewed and appraised based on their relation to the subject; the impact of DBPs on various cancers, and the subject-related contents and data were analyzed by the research team. In all processes, articles were appraised by two members of the research team and the points of differences in opinion were referred to a third arbitrator. Also, the research team contacted with the authors to obtain additional information, if necessary. Among all cancer types, the most relevant types were chosen and the relationship between them and DBPs was considered.

\section{Results}

Disinfection byproducts can cause many different types of cancers $(5,13,36)$, but some types are more likely to be developed due to exposure to DBPs. Previous studies showed that the most common cancers in laboratory animals, due to exposure to DBPs, are renal cancer, intestinal carcinoma, hepatocellular tumors, mesothelioma, and 
thyroid follicular cell tumor $(13,37)$. Some of them, like bromate, are probably human carcinogens too, meanwhile some are not known as human carcinogens yet $(13,38,39)$. But, as the liver and kidney are the most common target organs for toxicity, they are most likely to develop tumors in humans (5). In a recently published systematic review with the aim of detecting the populations and regions vulnerable to bladder and colorectal cancer due to exposure of DBPs, the incidence of the mentioned cancers among different groups of people have been discussed; furthermore, it has been determined that socio-demographic characteristics may play an important role as risk factors (40-45). Most common cancers related to DBPs are discussed in the following paragraphs and summarized in Table 1. Figure 1 illustrates how DBPs pass from gastrointestinal tract into the circulation system and damage the vital organs. The number of arrows shows the absorption rate of different sites in Figure 1.

\subsection{Intestine Cancer}

Intestine cancer is one of the most common carcinomas all around the world (65). Intestine cancer could have numerous reasons, but the most involving mechanisms of occurrence contain the association between insulinresistance and colonic adenoma, and epithelial barrier failure (66). The first mentioned mechanism can be a result of pancreas damage. On the other hand, most chemicals and toxins involve pancreas $(5,67)$. So, the chemicals, which hurt pancreas and involve its mechanisms, onset a cancerous intestine. The second mechanism, the damage of epithelial barrier, can also appear as a side-effect of exposure to chemicals. Trihalomethanes including bromodichloromethane, chlorodibromomethane, chlorodifluoromethane (CFC), chloroform, bromoform, and other similar compounds are the most common DBPs and top accusers of intestine cancer $(32,68-70)$. CFC is used as refrigerant and chloroform is also a useful solvent. According to previous researches, THMs can harm pancreas and cause intestine cancer by the first-mentioned mechanism $(5,71,72)$. They can cause pancreas cancer, too. Also, the impact of THMs on the epithelial tissue of intestine is proven $(52,73)$. So, both predicted mechanisms are involved in the process of exposure to THMs and pathology of intestine cancer. Limiting smoking and alcohol consumption, exercising regularly, and lowering the dietary fat are effective ways to help reducing pancreas-damage and epithelial barrier failure risk $(74,75)$. It is necessary to mention that a multicenter case-control study conducted in 2016 disproved the association of lifetime total THM exposure and colorectal cancer, but regarding the high heterogenicity in the observed sample, more studies are needed to prove the point (76).

\subsection{Renal Cancer}

Kidneys carry the important role of preserving homeostasis and omitting blood wastes. Renal cancer makes up more than one out of every 30 cancers worldwide (77). Obesity, cigarette smoking, hypertension, renal failure, change of lining tissue, diabetes mellitus, trichloroethylene exposure, and consumption of analgesics are known risk factors for renal cancer $(67,78-80)$. As THMs (bromodichloromethane and chloroform) affect the epithelial and lining tissues of organs, renal cancer is a possible result of THM exposure $(5,13,46)$. Bromate also increases the risk of kidney cancer by causing oxidative damage and inducing mutation to chromosomes in the kidney $(5,48)$. The mechanism of cancer occurrence by bromate may mostly lie on lipid peroxidation mechanism (81, 82). It is notable that lipid peroxidation increases in hypertension and obesity (81). So, both THMs and bromates have a positive effect on renal cancer occurrence. N-nitrosodimethylamine (NDMA) is another carcinogenic disinfection byproduct, which follows the mentioned mechanisms and exposure to NDMA leads to methylated bases forming in the genomes. The formation of O6-methylguanine as a result of NDMA N-demethylase enzyme activity could be responsible for the carcinogenicity of NDMA (49-51).

\subsection{Liver Cancer}

The liver plays the important role of detoxification in the human body and is the most exposed organ to toxins (27). Also, many chemicals can cause liver problems; for example, exposure to aflatoxin is a major risk factor for the pathology of liver cancer (65). Multiple DBPs can cause liver cancer, including THMs such as bromodichloromethane (13, 52), HAAs such as dichloroacetic acid and trichloroacetic acid (53, 83), and many unregulated DBPs (13). Chloroacetaldehyde, bromochloroacetic acid, bromodichloroacetic acid, dibromochloroacetic acid, dibromoacetic acid, chloral hydrate, and MX, are among those DBPs with a proven effect on increasing the risk of developing liver cancer (13, 54-57). Liver cancer due to exposure to chloroform and THMs is roughly related to cytotoxicity and cell multiplying in tissues (46). Haloacetic acids can cause harm by direct DNA damages and inhibiting glyceraldehyde-3-phosphate dehydrogenase (GAPDH) activity and, therefore, onset the carcinoma forming in livers (84). MX has a mutagenic nature and is responsible for near half of the mutagenic quiddity of chlorinated water (85). Ionization of DNA bases due to reductive feature of MX can cause DNA damage. Also, DNA adduction is another considered mechanism of mutation caused as a result of exposure to MX (61). Liver carcinomas due to exposure to dibromoacetic acid are supposed 


\begin{tabular}{|c|c|c|c|c|}
\hline Cancer Type & Known DBPs as Risk Factors & $\begin{array}{c}\text { Year of } \\
\text { Publication }\end{array}$ & Authors & Reference \\
\hline \multirow{2}{*}{ Intestine cancer } & \multirow{2}{*}{ Bromodichloromethane } & 2010 & Rahman et al. & $(32)$ \\
\hline & & 2018 & Benmarhnia et al. & $(40)$ \\
\hline \multirow{12}{*}{ Renal cancer } & \multirow{3}{*}{ Bromodichloromethane } & 2014 & Burcham et al. & (5) \\
\hline & & 2007 & Richardson et al. & $(13)$ \\
\hline & & 2004 & Komulainen et al. & $(46)$ \\
\hline & \multirow{4}{*}{ Chloroform } & 2014 & Burcham et al. & (5) \\
\hline & & 2007 & Richardson et al. & (13) \\
\hline & & 2004 & Komulainen et al. & $(46)$ \\
\hline & & 2017 & Jone et al. & (47) \\
\hline & \multirow{2}{*}{ Bromate } & 2014 & Burcham et al. & (5) \\
\hline & & 2006 & Moore et al. & $(48)$ \\
\hline & \multirow{3}{*}{ N-Nitrosodimethylamine } & 2002 & Choi et al. & $(49)$ \\
\hline & & 2000 & Fujioka et al. & $(50)$ \\
\hline & & 2007 & Arinç et al. & $(51)$ \\
\hline \multirow{15}{*}{ Liver cancer } & \multirow{2}{*}{ Bromodichloromethane } & 2007 & Richardson et al. & $(13)$ \\
\hline & & 2017 & El-Halim et al. & $(52)$ \\
\hline & \multirow{3}{*}{ Dichloroacetic acid } & 2017 & Yang et al. & (53) \\
\hline & & 2000 & Lash et al. & $(54)$ \\
\hline & & 2004 & Pereira et al. & $(55)$ \\
\hline & \multirow{2}{*}{ Trichloroacetic acid } & 2017 & Yang et al. & (53) \\
\hline & & 2000 & Lash et al. & $(54)$ \\
\hline & Dibromoacetic acid & 2007 & Melnick et al. & (56) \\
\hline & Chloroacetaldehyde & 2007 & Richardson et al. & $(13)$ \\
\hline & Bromodichloroacetic acid & 2007 & Richardson et al. & $(13)$ \\
\hline & Bromochloroacetic acid & 2007 & Richardson et al. & $(13)$ \\
\hline & Dibromochloroacetic acid & 2007 & Richardson et al. & (13) \\
\hline & Chloral hydrate & 2017 & Holmes et al. & $(57)$ \\
\hline & \multirow{2}{*}{ Mutagen X } & 2007 & Richardson et al. & (13) \\
\hline & & 2017 & Holmes et al. & $(57)$ \\
\hline \multirow{6}{*}{ Leukemia } & \multirow{2}{*}{ Dibromoacetic acid } & 2007 & Program et al. & (58) \\
\hline & & 2009 & Baccarelli et al. & (59) \\
\hline & Formaldehyde & 2010 & Zhang et al. & $(60)$ \\
\hline & \multirow{3}{*}{ Mutagen X } & 2007 & Richardson et al. & $(13)$ \\
\hline & & 2005 & McDonald et al. & $(61)$ \\
\hline & & 2009 & Zhang et al. & $(62)$ \\
\hline \multirow{5}{*}{ Thyroid cancer } & Bromate & 2014 & Bull et al. & (63) \\
\hline & \multirow{2}{*}{ Chlorate } & 2007 & Richardson et al. & (13) \\
\hline & & 2012 & Righi et al. & (64) \\
\hline & \multirow{2}{*}{ Mutagen X } & 2017 & Holmes et al. & (57) \\
\hline & & 2012 & Righi et al. & (64) \\
\hline \multirow{2}{*}{ Breast cancer } & \multirow{2}{*}{ Mutagen X } & 2007 & Richardson et al. & (13) \\
\hline & & 2005 & Mcdonald et al. & $(61)$ \\
\hline
\end{tabular}

Abbreviation: DBPs, disinfection byproducts.

to be part of the phenotype-based selective growth of a celltype (56). Hence, the liver is the main target of DBPs.

\subsection{Leukemia}

Apart from the types of leukemia, this type of cancer is broadly known as a lethal one (1). Alongside with hereditary factors, ionizing radiation is knowingly associ- 


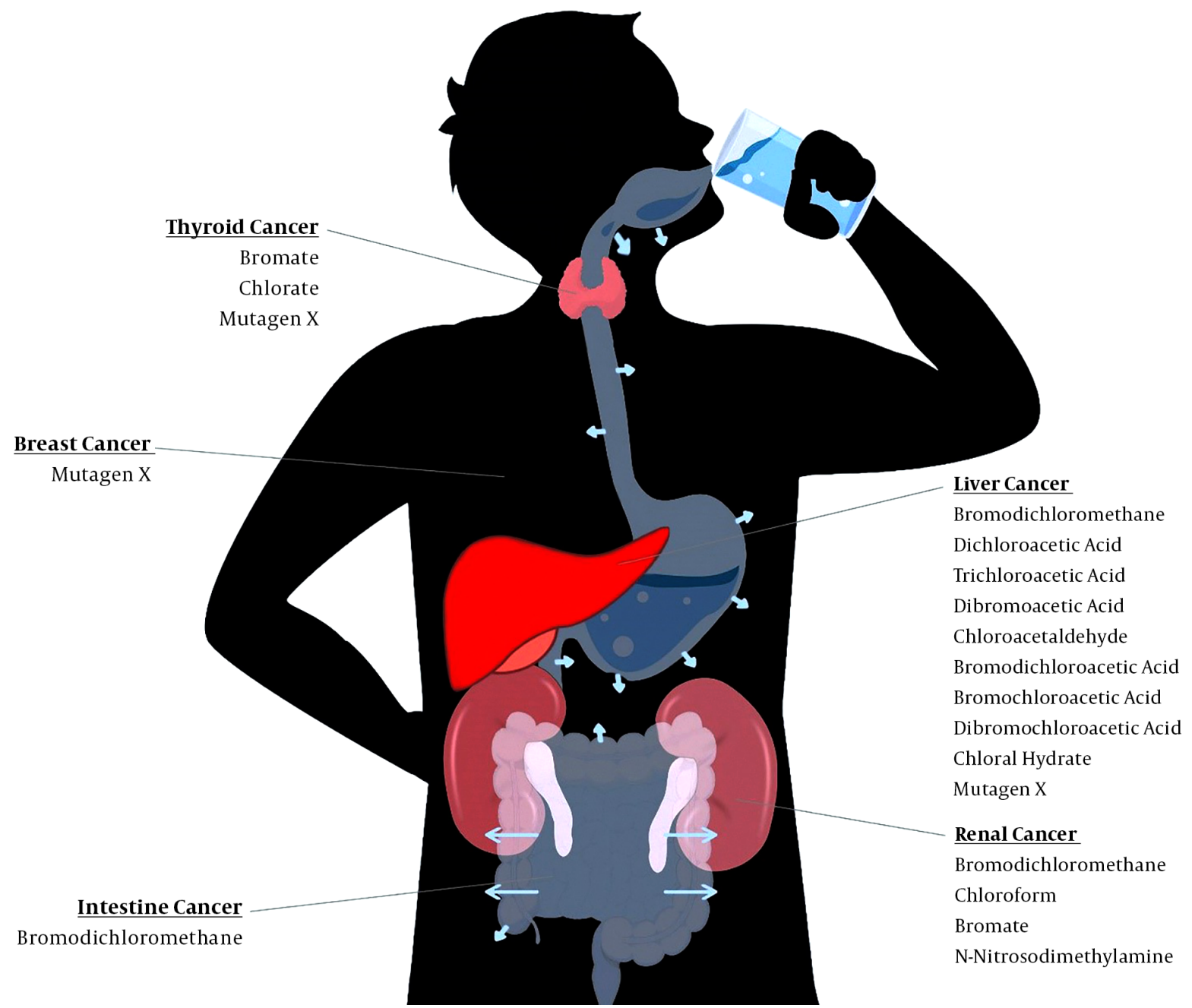

Figure 1. The absorption route of DBPs and the most influenced organs

ated with leukemia, accompanying by many environmental risk factors, such as cigarette smoking and electromagnetic fields (EMFs) (86). As witnessed in rats, leukemia could be associated with dibromoacetic acid exposure, as it is known to be carcinogen due to the peroxisome proliferation effect and cytotoxicity $(58,59)$. Also, Formaldehyde is carcinogenetic risk factors for leukemia, which affects DNA repair pathways and DNA damage responses (60). The invasion of bone marrow hematopoietic and blood stem cells are considered other possible mechanisms of the cancer pathology due to formaldehyde exposure (62). MX could also be mentioned as a leukemia inducer. Although the specific mechanism of MX carcinogenicity is uncertain, for its reductive characteristic, the ionization of DNA bases is the most considered mechanism of developing cancer- leading mutations due to MX exposure $(13,61)$. Chronic myeloid leukemia (CML) is the most common developed type as a result of exposure to DBPs (87).

\subsection{Thyroid Cancer}

Thyroid cancer is one of the most common endocrine carcinomas (88). Obesity, diet, lifestyle, radiation, and environmental pollutants are the most well-known risk factors for thyroid cancer (89). Bromate has a positive effect on the formation of thyroid malignancies by inducing the formation of 8-oxodeoxyguanosine (8-oxoG) in DNA and its products (63). The impact of chlorate and MX on thyroid cancer have also been discussed in previous studies and confirmatory evidence have been found $(13,64)$. The imitation of endocrine hormones could be a possible reason for the 
toxicity and carcinogenicity of MX and other hormone-like DBPs (57).

\subsection{Breast Cancer}

Breast cancer is the most diagnosed malignancy in the American women (90). Obesity, hormonal therapies, and genetic factors are the most common causes of breast cancer in women, alongside the exposure to chemicals (91). MX is the only known DBP that acts in the way of inducing breast cancer, as many other DBPs are not studied yet. The mechanism involving MX carcinogenicity could lie on the ionization of DNA bases and its mutation-inducing ability. DNA adduction may also be considered, but the certain mechanism is not specified yet $(13,61)$. As the breast cancer has got many more important risk factors, the effects of DBPs on this malignancy has not been a priority for previous researchers.

\subsection{Approaches to Remove DBPs from Drinking Water}

The main strategy for DBPs control is preventing their formation through NOM, major DBPs precursors, removal before peroxidation, and disinfection processes in treatment plants. However, after occurrence, drinking water DBPs can be reduced through different ways. Best available technologies include two precise methods: enhanced coagulation and granular activated carbon, commonly with an empty bed contact of 10 minutes have been suggested for DBPs removal (92). Granular activated carbon acts in two ways and reduces both DBPs and DBP precursors (93). Also, powdered activated carbon plays a positive role in the control of natural organic maters and DBPs (94). Pointof-use carbon devices are known as other useful carbondependent tools to control taste and odor of chlorine and its detrimental byproducts (95). Using membrane filters is another point of use removal technique that was also suggested for DBPs removal; however, in order to have a high removal efficiency, regular replacement, and orderly maintenance are necessary (96). Another established way to reduce DBPs in drinking water is the omission of prechlorination and changing the chlorination point to intermediate or post-chlorination, especially in large water systems (17). In this way, the application of chlorine dioxide is useful for reducing the impact of pre-chlorination elimination on latter therapeutic processes, and also augments the disinfection effect (97). Advanced oxidation processes such as plasma and ferrate-based processes are also studied for DBPs removal in lab scale; however, due to numerous degradation byproducts that is formed in this processes, more studies are required before their application in full scale water treatment plants $(18,23)$.
Regarding the differences in chemical interactions, effects, and properties of various disinfectants, replacing chlorine with other alternatives such as chloramines, ozone, chlorine dioxide, and UV is an effective way to lower the levels of DBPs (17, 98-102).

\section{Conclusions}

Based on the results of previous studies, liver and kidney are the most common target organs for toxicity by DBPs, which are on their way to becoming a major healthrelated problem, as the usage of disinfectants is increasing day by day and more cases get to be exposed. Bromodichloromethane and MX have been known as the most affecting risk factors in cause of most of the cancers. It has been offered reasonable and argumentative evidence on the carcinogenetic nature of most DBPs, as the animal laboratory studies confirm this claim, too. By passing time and showing up the crisis of by-products accumulation, the urgency of this issue becomes clearer. Providing safe drinking water resources, limiting the unreasonable usage of disinfectants, using the membrane filters, changing the chlorination point, and alternating disinfectants with less harmful DBPs could be the joint pin of further actions in this field. Further studies should be conducted, as the effects of many DBPs are not studied yet, due to their apparently less importance.

\section{Footnotes}

Authors' Contribution: All the authors contributed in conducting the research and writing the manuscript.

Conflict of Interests: The authors declare that there is no conflict of interest regarding the publication of this paper.

Financial Disclosure: It was not declared by the authors. Funding/Support: This research was supported by Tabriz University of Medical Sciences (Tabriz, Iran).

\section{References}

1. Siegel RL, Miller KD, Jemal A. Cancer statistics, 2016. CA Cancer J Clin 2016;66(1):7-30. doi: 10.3322/caac.21332. [PubMed: 26742998].

2. Kolahdoozan S, Sadjadi A, Radmard AR, Khademi H. Five common cancers in Iran. Arch Iran Med. 2010;13(2):143-6. [PubMed: 20187669].

3. Oppenheimer SB. Cellular basis of cancer metastasis: A review of fundamentals and new advances. Acta Histochem. 2006;108(5):327-34 doi:10.1016/j.acthis.2006.03.008. [PubMed:16730054].

4. Markowitz SD, Bertagnolli MM. Molecular origins of cancer: Molecular basis of colorectal cancer. N Engl J Med. 2009;361(25):2449-60. doi: 10.1056/NEJMra0804588. [PubMed: 20018966]. [PubMed Central: PMC2843693].

5. Burcham PC. Chemicals and Cancer. In: Burcham PC, editor. An Introduction to toxicology. London: Springer; 2014. p. 221-56. doi: 10.1007/978-1-4471-5553-9_8. 
6. Ruiz-Hernandez A, Kuo CC, Rentero-Garrido P, Tang WY, Redon J, Ordovas JM, et al. Environmental chemicals and DNA methylation in adults: A systematic review of the epidemiologic evidence. Clin Epigenetics. 2015;7:55. doi: 10.1186/s13148-015-0055-7. [PubMed: 25984247]. [PubMed Central: PMC4433069].

7. Salas LA, Bustamante M, Gonzalez JR, Gracia-Lavedan E, Moreno $\mathrm{V}$, Kogevinas $\mathrm{M}$, et al. DNA methylation levels and long-term trihalomethane exposure in drinking water: An epigenomewide association study. Epigenetics. 2015;10(7):650-61. doi: 10.1080/15592294.2015.1057672. [PubMed: 26039576]. [PubMed Central: PMC4622514].

8. Liviac D, Creus A, Marcos R. DNA damage induction by two halogenated acetaldehydes, byproducts of water disinfection. Water Res. 2010;44(8):2638-46. doi: 10.1016/j.watres.2010.01.026. [PubMed: 20189624].

9. Ranmuthugala G, Pilotto L, Smith W, Vimalasiri T, Dear K, Douglas R. Chlorinated drinking water and micronuclei in urinary bladder epithelial cells. Epidemiology. 2003;14(5):617-22. doi: 10.1097/01.ede.0000082374.08684.0d. [PubMed: 14501278].

10. Eryilmaz M. New generation disinfectants.JPharm Microbiol.2016;2(1)

11. Fernandez-Navarro P, Villanueva CM, Garcia-Perez J, Boldo E, GoniIrigoyen F, Ulibarrena E, et al. Chemical quality of tap water in Madrid: Multicase control cancer study in Spain (MCC-Spain). Environ Sci Pollut Res Int. 2017;24(5):4755-64. doi: 10.1007/s11356-016-8203-y. [PubMed: 27981479].

12. Wild S. A quick guide to disinfectants. Vet Nurs J. 2017;32(12):375-8. doi: 10.1080/17415349.2017.1385433.

13. Richardson SD, Plewa MJ, Wagner ED, Schoeny R, Demarini DM. Occurrence, genotoxicity, and carcinogenicity of regulated and emerging disinfection by-products in drinking water: A review and roadmap for research. Mutat Res. 2007;636(1-3):178-242. doi: 10.1016/j.mrrev.2007.09.001. [PubMed:17980649].

14. Plewa MJ, Wagner ED, Jazwierska P, Richardson SD, Chen PH, McKague AB. Halonitromethane drinking water disinfection byproducts: Chemical characterization and mammalian cell cytotoxicity and genotoxicity. Environ Sci Technol. 2004;38(1):62-8. doi: 10.1021/es030477l. [PubMed: 14740718].

15. Aslani H, Nabizadeh R, Alimohammadi M, Mesdaghinia A, Nadafi $\mathrm{K}$, Nemati R, et al. Disinfection of raw wastewater and activated sludge effluent using Fenton like reagent. J Environ Health Sci Eng. 2014;12(1):149. doi: 10.1186/s40201-014-0149-8. [PubMed: 25606344]. [PubMed Central: PMC4299597].

16. Zhang L, Fang M. Nanomaterials in pollution trace detection and environmental improvement. Nano Today. 2010;5(2):128-42. doi 10.1016/j.nantod.2010.03.002.

17. Xie YF. Disinfection byproducts in drinking water: Formation, analysis, and control. New York: CRC press; 2016.

18. Aslani H, Nasseri S, Nabizadeh R, Mesdaghinia A, Alimohammadi M, Nazmara S. Haloacetic acids degradation by an efficient Ferrate/UV process: Byproduct analysis, kinetic study, and application of response surface methodology for modeling and optimization. J Environ Manage. 2017;203(Pt 1):218-28. doi: 10.1016/j.jenvman.2017.07.072. [PubMed: 28783018].

19. DeAngelo AB, Jones CP, Moyer MP. Development of normal human colon cell cultures to identify priority unregulated disinfection by-products with a carcinogenic potential. Water Sci Technol. 2007;56(12):51-5. doi: 10.2166/wst.2007.830. [PubMed: 18075178].

20. Regli S, Chen J, Messner M, Elovitz MS, Letkiewicz FJ, Pegram RA, et al. Estimating potential increased bladder cancer risk due to increased bromide concentrations in sources of disinfected drinking waters. Environ Sci Technol. 2015;49(22):13094-102. doi: 10.1021/acs.est.5b03547. [PubMed: 26489011].

21. Pan S, An W, Li H, Su M, Zhang J, Yang M. Cancer risk assessment on trihalomethanes and haloacetic acids in drinking water of China using disability-adjusted life years.J Hazard Mater. 2014;280:288-94. doi: 10.1016/j.jhazmat.2014.07.080. [PubMed: 25171513].
22. Lee SC, Guo H, Lam SM, Lau SL. Multipathway risk assessment on disinfection by-products of drinking water in Hong Kong. Environ Res. 2004;94(1):47-56. doi: 10.1016/S0013-9351(03)00067-7. [PubMed: 14643286].

23. Aslani H, Nabizadeh R, Nasseri S, Mesdaghinia A, Alimohammadi M, Mahvi AH, et al. Application of response surface methodology for modeling and optimization of trichloroacetic acid and turbidity removal using potassium ferrate(VI). Desalination and Water Treatment. 2016;57(52):25317-28. doi: 10.1080/19443994.2016.1147380.

24. Lu G, Qin D, Wang Y, Liu J, Chen W. Single and combined effects of selected haloacetonitriles in a human-derived hepatoma line. Ecotoxicol Environ Saf. 2018;163:417-26. doi: 10.1016/j.ecoenv.2018.07.104. [PubMed: 30071462].

25. Xu T, Yin J, Chen S, Zhang D, Wang H. Elevated 8-oxo-7,8-dihydro2'-deoxyguanosine in genome of T24 bladder cancer cells induced by halobenzoquinones. J Environ Sci (China). 2018;63:133-9. doi: 10.1016/j.jes.2017.05.024. [PubMed: 29406097].

26. Landecker $\mathrm{H}$. Antibiotic resistance and the biology of history. Body Soc. 2016;22(4):19-52. doi: 10.1177/1357034X14561341. [PubMed: 28458609]. [PubMed Central: PMC5390938].

27. Bull RJ, Birnbaum LS, Cantor KP, Rose JB, Butterworth BE, Pegram R, et al. Water chlorination: Essential process or cancer hazard? Fundam Appl Toxicol. 1995;28(2):155-66. doi: 10.1006/faat.1995.1156. [PubMed: 8835225].

28. Pilotto LS. Disinfection of drinking water, disinfection by-products and cancer: What about Australia? Aust J Public Health. 1995;19(1):8993. doi: 10.1111/j.1753-6405.1995.tb00304.x. [PubMed: 7734603].

29. Morris RD, Audet AM, Angelillo IF, Chalmers TC, Mosteller F. Chlorination, chlorination by-products, and cancer: A meta-analysis. Am J Public Health. 1992;82(7):955-63. doi: 10.2105/ajph.82.7.955. [PubMed: 1535181]. [PubMed Central: PMC1694065].

30. Lachenmeier DW. Antiseptic Drugs and Disinfectants. Side Effects Drug Annu. 2016;38:211-6. doi:10.1016/bs.seda.2016.07.006.

31. Bull RJ, Robinson M, Meier JR, Stober J. Use of biological assay systems to assess the relative carcinogenic hazards of disinfection by-products. Environ Health Perspect. 1982;46:215-27. doi: 10.1289/ehp.8246215. [PubMed: 7151763]. [PubMed Central: PMC1569044].

32. Rahman MB, Driscoll T, Cowie C, Armstrong BK. Disinfection byproducts in drinking water and colorectal cancer: A meta-analysis. Int J Epidemiol. 2010;39(3):733-45. doi: 10.1093/ije/dyp371. [PubMed: 20139236].

33. Villanueva CM, Cantor KP, Grimalt JO, Malats N, Silverman D, Tardon A, et al. Bladder cancer and exposure to water disinfection by-products through ingestion, bathing, showering, and swimming in pools. Am J Epidemiol. 2007;165(2):148-56. doi: 10.1093/aje/kwj364. [PubMed: 17079692].

34. Castano-Vinyals G, Cantor KP, Villanueva CM, Tardon A, Garcia-Closas $\mathrm{R}$, Serra C, et al. Socioeconomic status and exposure to disinfection by-products in drinking water in Spain. Environ Health. 2011;10:18. doi: 10.1186/1476-069X-10-18. [PubMed: 21410938]. [PubMed Central: PMC3068078].

35. Nieuwenhuijsen MJ, Grellier J, Smith R, Iszatt N, Bennett J, Best $\mathrm{N}$, et al. The epidemiology and possible mechanisms of disinfection by-products in drinking water. Philos Trans A Math Phys Eng Sci. 2009;367(1904):4043-76. doi: 10.1098/rsta.2009.0116. [PubMed: 19736233].

36. Tsitsifli S, Kanakoudis V. Disinfection impacts to drinking water safety-A review. Proceedings. 2018;2(11):603. doi: 10.3390/proceedings2110603.

37. Koivusalo M, Vartiainen T. Drinking water chlorination byproducts and cancer. Rev Environ Health. 1997;12(2):81-90. doi: 10.1515/REVEH.1997.12.2.81. [PubMed: 9273924].

38. IARC Working Group on the Evaluation of Carcinogenic Risks to Humans; World Health Organization; International Agency for Research on Cancer. Some drinking-water disinfectants and contaminants, includ- 
ing arsenic. IARC; 2004.

39. McDorman KS, Pachkowski BF, Nakamura J, Wolf DC, Swenberg JA. Oxidative DNA damage from potassium bromate exposure in LongEvans rats is not enhanced by a mixture of drinking water disinfection by-products. Chem Biol Interact. 2005;152(2-3):107-17. doi: 10.1016/j.cbi.2005.02.003. [PubMed:15840384].

40. Benmarhnia T, Delpla I, Schwarz L, Rodriguez MJ, Levallois P. Heterogeneity in the relationship between disinfection by-products in drinking water and cancer: A systematic review. Int J Environ Res Public Health. 2018;15(5). doi: 10.3390/ijerph15050979. [PubMed: 29757939]. [PubMed Central: PMC5982018].

41. Villanueva CM, Cordier S, Font-Ribera L, Salas LA, Levallois P. overview of disinfection by-products and associated health effects. Curr Environ Health Rep. 2015;2(1):107-15. doi: 10.1007/s40572-014-0032-x. [PubMed: 26231245].

42. Kogevinas M. Epidemiological approaches in the investigation of environmental causes of cancer: the case of dioxins and water disinfection by-products. Environ Health. 2011;10 Suppl 1. S3. doi: 10.1186/1476069X-10-S1-S3. [PubMed: 21489213]. [PubMed Central: PMC3073195].

43. Chang CC, Ho SC, Wang LY, Yang CY. Bladder cancer in Taiwan: Relationship to trihalomethane concentrations present in drinkingwater supplies. J Toxicol Environ Health A. 2007;70(20):1752-7. doi: 10.1080/15287390701459031. [PubMed: 17885932].

44. Wigle DT. Safe drinking water: A public health challenge. Chronic Dis Can.1998;19(3):103-7. [PubMed: 9820833]

45. Cotruvo JA, Amato H. National trends of bladder cancer and trihalomethanes in drinking water: A review and multicountry ecological study. Dose Response. 2019;17(1):1-19. doi: 10.1177/1559325818807781. [PubMed: 30718988]. [PubMed Central: PMC6348529].

46. Komulainen $H$. Experimental cancer studies of chlorinated by-products. Toxicology. 2004;198(1-3):239-48. doi: 10.1016/j.tox.2004.01.031. [PubMed: 15138047].

47. Jones RR, Weyer PJ, DellaValle CT, Robien K, Cantor KP, Krasner $S$, et al. Ingested nitrate, disinfection by-products, and kidney cancer risk in older women. Epidemiology. 2017;28(5):703-11. doi: 10.1097/EDE.0000000000000647. [PubMed: 28252454]. [PubMed Central: PMC5538922].

48. Moore MM, Chen T. Mutagenicity of bromate: Implications for cancer risk assessment. Toxicology. 2006;221(2-3):190-6. doi: 10.1016/j.tox.2005.12.018. [PubMed: 16460860].

49. Choi J, Valentine RL. Formation of N-nitrosodimethylamine (NDMA) from reaction of monochloramine: A new disinfection by-product. Water Res. 2002;36(4):817-24. doi: 10.1016/S0043-1354(01)00303-7. [PubMed: 11848351].

50. Fujioka T, Suzuki Y, Okamoto T, Mastushita N, Hasegawa M, Omori S. Prevention of renal cell carcinoma by active vitamin D3. World J Surg. 2000;24(10):1205-10. doi: 10.1007/s002680010206. [PubMed: 11071463].

51. Arinc E, Arslan S, Bozcaarmutlu A, Adali O. Effects of diabetes on rabbit kidney and lung CYP2E1 and CYP2B4 expression and drug metabolism and potentiation of carcinogenic activity of $\mathrm{N}$-nitrosodimethylamine in kidney and lung. Food Chem Toxicol. 2007;45(1):107-18. doi: 10.1016/j.fct.2006.07.026. [PubMed: 17034923].

52. El-Halim MA, Mohammed SY, Idris OF, Sabahelkhier MK. Histopathological effect on different rat tissues induced by the trihalomethanechloroform administered in drinking water. Int $J$ Adv Res. 2015;3(11):1319-29.

53. Yang L, She Q, Wan MP, Wang R, Chang VW, Tang CY. Removal of haloacetic acids from swimming pool water by reverse osmosis and nanofiltration. Water Res. 2017;116:116-25. doi: 10.1016/j.watres.2017.03.025. [PubMed: 28324708].

54. Lash LH, Fisher JW, Lipscomb JC, Parker IC. Metabolism of trichloroethylene. Environ Health Perspect. 2000;108 Suppl 2:177200. doi: 10.1289/ehp.00108s2177. [PubMed: 10807551]. [PubMed Central: PMC1637769].

55. Pereira MA, Wang W, Kramer PM, Tao L. Prevention by methionine of dichloroacetic acid-induced liver cancer and DNA hypomethylation in mice. Toxicol Sci. 2004;77(2):243-8. doi: 10.1093/toxsci/kfh031. [PubMed: 14657517].

56. Melnick RL, Nyska A, Foster PM, Roycroft JH, Kissling GE. Toxicity and carcinogenicity of the water disinfection byproduct, dibromoacetic acid, in rats and mice. Toxicology. 2007;230(2-3):126-36. doi: 10.1016/j.tox.2006.11.006. [PubMed: 17157429]. [PubMed Central PMC1905493].

57. Holmes BE, Smeester L, Fry RC, Weinberg HS. Identification of endocrine active disinfection by-products (DBPs) that bind to the androgen receptor. Chemosphere. 2017;187:114-22. doi: 10.1016/j.chemosphere.2017.08.105. [PubMed: 28843117]

58. National Toxicology P. Toxicology and carcinogenesis studies of dibromoacetic acid (Cas No. 631-64-1) in F344/N rats and B6C3F1 mice (drinking water studies). Natl Toxicol Program Tech Rep Ser. 2007;(537):1-320. [PubMed:17554398].

59. Baccarelli A, Bollati V. Epigenetics and environmental chemicals. Curr Opin Pediatr. 2009;21(2):243-51. doi: 10.1097/MOP.0b013e32832925cc. [PubMed: 19663042]. [PubMed Central: PMC3035853].

60. Zhang L, Freeman LE, Nakamura J, Hecht SS, Vandenberg JJ, Smith MT, et al. Formaldehyde and leukemia: Epidemiology, potential mechanisms, and implications for risk assessment. Environ $\mathrm{Mol} \mathrm{Mu}$ tagen. 2010;51(3):181-91. doi: 10.1002/em.20534. [PubMed: 19790261]. [PubMed Central: PMC2839060].

61. McDonald TA, Komulainen H. Carcinogenicity of the chlorination disinfection by-product MX. J Environ Sci Health C Environ Carcinog Ecotoxicol Rev. 2005;23(2):163-214. doi: 10.1080/10590500500234988. [PubMed: 16291527].

62. Zhang L, Steinmaus C, Eastmond DA, Xin XK, Smith MT Formaldehyde exposure and leukemia: A new meta-analysis and potential mechanisms. Mutat Res. 2009;681(2-3):150-68. doi: 10.1016/j.mrrev.2008.07.002. [PubMed: 18674636].

63. Bull RJ, Cotruvo JA. Nongenotoxic mechanisms involved in bromate-induced cancer in rats. Ozone Sci Eng. 2014;36(5):419-21. doi: 10.1080/01919512.2014.941762.

64. Righi E, Bechtold P, Tortorici D, Lauriola P, Calzolari E, Astolfi G, et al Trihalomethanes, chlorite, chlorate in drinking water and risk of congenital anomalies: A population-based case-control study in Northern Italy. Environ Res. 2012;116:66-73. doi: 10.1016/j.envres.2012.04.014. [PubMed: 22578809]

65. Stewart B, Wild CP. World cancer report 2014. Public Health Well; 2017.

66. Bruce WR, Giacca A, Medline A. Possible mechanisms relating diet and risk of colon cancer. Cancer Epidemiol Biomarkers Prev. 2000;9(12):1271-9. [PubMed: 11142411]

67. Quist AJL, Inoue-Choi M, Weyer PJ, Anderson KE, Cantor KP, Krasner $\mathrm{S}$, et al. Ingested nitrate and nitrite, disinfection by-products, and pancreatic cancer risk in postmenopausal women. Int J Cancer. 2018;142(2):251-61. doi: 10.1002/ijc.31055. [PubMed: 28921575]. [PubMed Central: PMC5788281].

68. Krasner SW, Cantor KP, Weyer PJ, Hildesheim M, Amy G. Case study approach to modeling historical disinfection by-product exposure in Iowa drinking waters. J Environ Sci (China). 2017;58:183-90. doi: 10.1016/j.jes.2017.03.007. [PubMed: 28774607].

69. Chowdhury S. Predicting human exposure and risk from chlorinated indoor swimming pool: A case study. Environ Monit Assess. 2015;187(8):502. doi: 10.1007/s10661-015-4719-8. [PubMed: 26164734].

70. Rahman MB, Cowie C, Driscoll T, Summerhayes RJ, Armstrong BK, Clements MS. Colon and rectal cancer incidence and water trihalomethane concentrations in New South Wales, Australia. BMC Cancer. 2014;14:445. doi: 10.1186/1471-2407-14-445. [PubMed: 24938491]. [PubMed Central: PMC4088985].

71. Nikfam S, Pourshams A. A systematic review of environmental risk factors for pancreatic cancer. Govaresh. 2012;16(4):258-64.

72. Chiu HF, Tsai SS, Wu TN, Yang CY. Effect modification of the association between trihalomethanes and pancreatic cancer by drinking water hardness: Evidence from an ecological study. Environ 
Res. 2010;110(5):513-8. doi: 10.1016/j.envres.2010.03.007. [PubMed: 20382379].

73. Landi S, Naccarati A, Ross MK, Hanley NM, Dailey L, Devlin RB, et al. Induction of DNA strand breaks by trihalomethanes in primary human lung epithelial cells. Mutat Res. 2003;538(1-2):41-50. doi: 10.1016/S13835718(03)00086-X. [PubMed: 12834753].

74. Tenner S, Baillie J, DeWitt J, Vege SS; American College of Gastroenterology. American College of Gastroenterology guideline: Management of acute pancreatitis. Am J Gastroenterol. 2013;108(9):1400-15. 1416. doi: 10.1038/ajg.2013.218. [PubMed: 23896955].

75. Turner JR. Molecular basis of epithelial barrier regulation: From basic mechanisms to clinical application. Am J Pathol. 2006;169(6):1901-9. doi: 10.2353/ajpath.2006.060681. [PubMed: 17148655]. [PubMed Central: PMC1762492].

76. Villanueva CM, Gracia-Lavedan E, Bosetti C, Righi E, Molina AJ, Martin $\mathrm{V}$, et al.Colorectal cancer and long-term exposure to trihalomethanes in drinking water: A multicenter case-control study in Spain and italy. Environ Health Perspect. 2017;125(1):56-65. doi: 10.1289/EHP155. [PubMed: 27383820]. [PubMed Central: PMC5226692 interests].

77. Cognard N, Anglicheau D, Gatault P, Girerd S, Essig M, Hurault de Ligny B, et al. Recurrence of renal cell cancer after renal transplantation in a multicenter French cohort. Transplantation. 2018;102(5):8607. doi: 10.1097/TP.0000000000002009. [PubMed: 29215458].

78. Rini BI, Campbell SC, Escudier B. Renal cell carcinoma. Lancet. 2009;373(9669):1119-32. doi: 10.1016/S0140-6736(09)60229-4. [PubMed: 19269025].

79. Ishikawa I, Saito Y, Asaka M, Tomosugi N, Yuri T, Watanabe M, et al. Twenty-year follow-up of acquired renal cystic disease. Clin Nephrol. 2003;59(3):153-9. doi: 10.5414/CNP59153. [PubMed: 12653256].

80. Chow WH, Dong LM, Devesa SS. Epidemiology and risk factors for kidney cancer. Nat Rev Urol. 2010;7(5):245-57. doi: 10.1038/nrurol.2010.46. [PubMed: 20448658]. [PubMed Central: PMC3012455].

81. Gago-Dominguez M, Castelao JE, Yuan JM, Ross RK, Yu MC. Lipid peroxidation: A novel and unifying concept of the etiology of renal cell carcinoma (United States). Cancer Causes Control. 2002;13(3):287-93. doi: 10.1023/A:1015044518505. [PubMed: 12020111].

82. Khan N, Sultana S. Abrogation of potassium bromate-induced renal oxidative stress and subsequent cell proliferation response by soy isoflavones in Wistar rats. Toxicology. 2004;201(1-3):173-84. doi: 10.1016/j.tox.2004.04.012. [PubMed: 15297031].

83. National Toxicology Program. NTP report on the toxicology studies of dichloroacetic acid (CAS No. 79-43-6) in genetically modified (FVB Tg.AC hemizygous) mice (dermal and drinking water studies) and carcinogenicity studies of dichloroacetic acid in genetically modified [B6.129-Trp53(tm1Brd) (N5) haploinsufficient] mice (drinking water studies). Natl Toxicol Program Genet ModifModel Rep. 2007;(11):1-168. [PubMed: 18784768]

84. Pals JA, Ang JK, Wagner ED, Plewa MJ. Biological mechanism for the toxicity of haloacetic acid drinking water disinfection byproducts. Environ Sci Technol.2011;45(13):5791-7. doi:10.1021/es2008159. [PubMed: 21671678].

85. Woo YT, Lai D, McLain JL, Manibusan MK, Dellarco V. Use of mechanism-based structure-activity relationships analysis in carcinogenic potential ranking for drinking water disinfection by-products. Environ Health Perspect. 2002;110 Suppl 1:75-87. doi: 10.1289/ehp.02110s175. [PubMed: 11834465]. [PubMed Central: PMC1241149].

86. Belson M, Kingsley B, Holmes A. Risk factors for acute leukemia in children: A review. Environ Health Perspect. 2007;115(1):138-45. doi: 10.1289/ehp.9023. [PubMed: 17366834]. [PubMed Central: PMC1817663].

87. Kasim K, Levallois P, Johnson KC, Abdous B, Auger P; Canadian Cancer Registries Epidemiology Research Group. Chlorination disinfec- tion by-products in drinking water and the risk of adult leukemia in Canada. Am J Epidemiol. 2006;163(2):116-26. doi: 10.1093/aje/kwj020. [PubMed: 16319293].

88. Figge JJ. Epidemiology of Thyroid Cancer. In: Wartofsky L, Van Nostrand D, editors. Thyroid cancer. New York: Springer; 2016. p. 9-15. doi: 10.1007/978-1-4939-3314-3_2.

89. Pellegriti G, Frasca F, Regalbuto C, Squatrito S, Vigneri R. Worldwide increasing incidence of thyroid cancer: Update on epidemiology and risk factors. J Cancer Epidemiol. 2013;2013:965212. doi: 10.1155/2013/965212. [PubMed: 23737785]. [PubMed Central: PMC3664492].

90. Ma J, Jemal A. Breast cancer statistics. In: Ahmad A, editor. Breast cancer metastasis and drug resistance. New York: Springer; 2013. p.1-18. doi: 10.1007/978-1-4614-5647-6_1.

91. Kaminska M, Ciszewski T, Lopacka-Szatan K, Miotla P, Staroslawska E. Breast cancer risk factors. Prz Menopauzalny. 2015;14(3):196-202. doi: 10.5114/pm.2015.54346. [PubMed: 26528110]. [PubMed Central: PMC4612558].

92. Barrett SE, Krasner SW, Amy GL. Natural organic matter and disinfection by-products characterization and control in drinking water. Am Chem Soc. 2000;761. doi: 10.1021/bk-2000-0761.

93. L. Bao M, Griffini O, Santianni D, Barbieri K, Burrini D, Pantani F. Removal of bromate ion from water using granular activated carbon. Water Research. 1999;33(13):2959-70. doi: 10.1016/s00431354(99)00015-9.

94. Kristiana I, Joll C, Heitz A. Powdered activated carbon coupled with enhanced coagulation for natural organic matter removal and disinfection by-product control: Application in a Western Australian water treatment plant. Chemosphere. 2011;83(5):661-7. doi: 10.1016/j.chemosphere.2011.02.017. [PubMed: 21353285].

95. Jordan FL, Seaman R, Riley JJ, Yoklic MR. Effective removal of microbial contamination from harvested rainwater using a simple point of use filtration and UV-disinfection device. Urban Water J. 2008;5(3):209-18. doi: 10.1080/15730620801977174

96. Dehghanzadeh R, Talebzadeh N, Taghipour H, Aslani H. Evaluation impact of point of use (POU) household water treatment devices (HWTDs)application on tap water quality and determine the removal efficiency of THMs and HAAs. Desalin Water Treat. 2018;105:62-72. doi: 10.5004/dwt.2018.21987.

97. Lykins BW, Griese MH. Using chlorine dioxide for trihalomethane control. J Am Water Works Assoc. 1986;78(6):88-93. doi: 10.1002/j.15518833.1986.tb05769.x.

98. Ramseier MK, von Gunten U, Freihofer P, Hammes F. Kinetics of membrane damage to high (HNA) and low (LNA) nucleic acid bacterial clusters in drinking water by ozone, chlorine, chlorine dioxide, monochloramine, ferrate(VI), and permanganate. Water Res. 2011;45(3):1490-500. doi: 10.1016/j.watres.2010.11.016. [PubMed: 21146846].

99. Fiessinger F, Rook JJ, Duguet JP. Alternative methods for chlorination. Sci Total Environ. 1985;47:299-315. doi: 10.1016/0048-9697(85)90338-9. [PubMed: 4089604].

100. Liu W, Cheung LM, Yang X, Shang C. THM, HAA and $\mathrm{CNCl}$ formation from UV irradiation and chlor(am)ination of selected organic waters. Water Res. 2006;40(10):2033-43. doi: 10.1016/j.watres.2006.03.019. [PubMed: 16678880].

101. Nakada LYK, Franco RMB, Fiuza V, Santos LUD, Branco N, Guimaraes JR. Pre-ozonation of source water: Assessment of efficacy against Giardia duodenalis cysts and effects on natural organic matter. Chemosphere. 2019;214:764-70. doi: 10.1016/j.chemosphere.2018.09.164. [PubMed: 30296764].

102. Chevrier C, Junod B, Cordier S. Does ozonation of drinking water reduce the risk of bladder cancer? Epidemiology. 2004;15(5):605-14. doi: 10.1097/01.ede.0000134866.61780.28. [PubMed:15308961]. 